\title{
有明海湾奥部における底質の堆積環境特性と底生生物の分布特性
}

\section{Sedimentation Environment Characteristics of Bottom Material and Distribution Characteristics of Benthos in the Inner Area of the Ariake Sea}

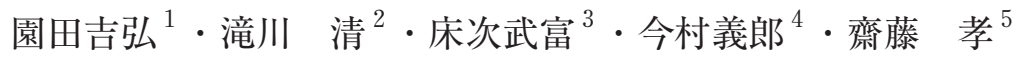 \\ Yoshihiro SONODA, Kiyoshi TAKIKAWA, Taketomi TOKONAMI \\ Yoshiro IMAMURA and Takashi SAITO
}

\begin{abstract}
The sedimentation environment characteristics and distribution characteristics of benthos were studied based on the past investigation data of bottom material, water quality, benthos, tidal current and investigation data of fluid mud layer in the inner area of the Ariake Sea. It is suggested that the change of kind number of benthos was corresponds to the degree of bottom environment deterioration shown in mud content, ignition loss and AVS (acid volatile sulfides). By the geographic distribution of layer thickness, it is suggested that fluid mud layer was precipitated the west slopes of submarine channels and the east slopes of submarine sandbars where there were located at the outside of tidal current.
\end{abstract}

\section{1.はじめに}

有明海は，近年，生物相の変化と種の激減，赤潮の多 発，水質・底質の罒化など環境悪化が著しい。海域環境 は物理・化学的要因や, これに生物系の要素が加わる複 雑系であり総合的な視点からの調査・分析が重要である が，有明海においてはこのような視点からの研究成果， 知見が少なく, 研究の必要性が指摘されている. 園田ら （2008a，2008b，2009）は，有明海における底質環境特 性, 水質環境特性と底生生物の分布特性について研究を 行った.その中で, 底質データのクラスター分析から, 海 域グループは含泥率によって明暸に区分されるが，同じ 海域グループの底質中の硫化物や強熱減量等は海域によ って大きく変動すること, 底生生物の種数や個体数の変 動が, 含泥率の変動だけではなく, 強熱減量, 硫化物等 によってあらわされる全体的な底質環境特性の変動に密 接に関連していることを明らかにした。底質環境特性と 底生生物の分布特性に関して, 古賀（1991）は, 有明海 湾奥部を対象として含泥率, 強熱減量, 硫化物等により クラスター分析を行って海域を区分し, 底生生物の個体 数等を海域区分別に比較し，底生生物の分布傾向と底質 環境特性との関係を定性的に検討した. また, 安藤ら （2007）は, 東京湾を対象として底生生物種の出現率に よりクラスター分析を行って海域を区分し, 各区分に出 現する環境指標種から海域の污染度を検討している.

\begin{tabular}{ll}
\hline 1 & 正会員 \\
2 & フェロー 工博 \\
& \\
3 & \\
4 & \\
5 & 学生会員
\end{tabular}

熊本大学大学院自然科学研究科

熊本大学沿岸域環境科学教育研究センタ 一教授

九州農政局整備部農地整備課課長補佐 九州農政局整備部農地整備課係長 熊本大学大学院自然科学研究科
本研究では，これまでの研究成果を踏まえ，底質環境 特性と底生生物分布特性を同時に用いてクラスター分析 等を行い, これらの関連をより総合的, 定量的に評価す るとともに, 水質, 海底地形, 潮流および浮泥の堆積の 経時変化との関連性を解析して有明海湾奥部における底 泥の堆積環境を明らかにしょうとするものである.

\section{2. 底質環境特性}

有明海湾奥部海域における, 底質環境特性の地域的な 分布を調べるために, 大隈ら（2001）による54地点の底 質・底生生物調査データにより, クラスター分析を行っ た。底質・底生調査地点を図-1に示す。

クラスター分析のデータセットは, 含泥率, AVS（酸 揮発性硫化物), 強熱減量の 3 項目である. クラスター分 析の手法は, データは全て独立した初期状態から始めて, クラスタ間を平方ユークリッド距離により計算し, 最も この距離が近いものから逐次クラスタを併合し, 全ての データが一つのクラスタに併合されるまで繰り返すWard 法による凝集型階層的手法である（棟近ら，2007）.

クラスター分析の結果, 図-2に示すような $5 つ$ の海域

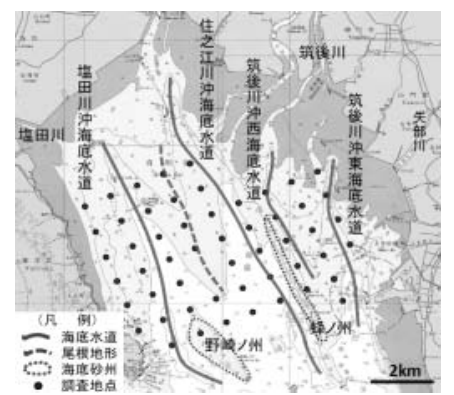

図-1 底質・底生生物調查地点（2000年9月） 
に分類された。また，海域別の底質環境特性を図-3（a） 〜 (c) に示す.これらの図から，A海域は中央值で含泥 率が $97 \%$, 強熱減量が $15 \mathrm{mg} / \mathrm{g}$, AVSが $0.5 \mathrm{mg} / \mathrm{g}$ を示し, 最も泥化, 嫌気化, 過栄養化が進んでいる. B 海域は, 中央值で含泥率が $88 \%$, 強熱減量が $14 \mathrm{mg} / \mathrm{g}, \mathrm{AVS}$ が $0.4 \mathrm{mg} / \mathrm{g}$ を示し, A海域の次に泥化, 嫌気化, 過栄養化が 進んでいる，C海域は，中央值で含泥率が $60 \%$ ，強熱減 量が $9 \mathrm{mg} / \mathrm{g} ，$ AVSが $0.2 \mathrm{mg} / \mathrm{g}$ を示し，A，B海域ほどは底 質の悪化が進んでいない，D海域は，中央值で含泥率が $40 \%$ を示し，砂分が泥分より多い。強熱減量は $7 \mathrm{mg} / \mathrm{g}$, AVSは $0.1 \mathrm{mg} / \mathrm{g}$ を示し，底質の悪化が進んでいない.E海 域は, 中央值で含泥率が $30 \%$ の砂質で, 強熱減量は $5 \mathrm{mg} / \mathrm{g}, \quad$ AVSは $0.04 \mathrm{mg} / \mathrm{g}$ を示し，最も嫌気化，富栄養化 が進んでいない底質環境である。なお，図-2に示した覆 砂施工区域周辺は，底質が局部的に変化し自然の海底環 境と著しく異なるため，海域区分の表示をしていない.

\section{3. 水質環境特性}

佐賀県と福岡県による浅海定線調査デー夕の中から， 底質・底生生物の調査が行われた時期のデー夕を選び, Ward法による凝集型階層的クラスター分析を行った。

使用した水質デー夕は，2000年の 7〜9月の毎月の底 層デー夕（海底上 $1 \mathrm{~m}$ 層）であり，水温，塩分，溶存酸 素，透明度， $\mathrm{COD}, \mathrm{DIN}, \mathrm{PO}_{4}-\mathrm{P}$ の7項目である。クラス 夕ー分析の結果，図-4 に示すような 6 つの海域に分類さ れた。

海域区分別にみると，図-5（a）のDOは，V海域が最 も低く, 中央值で $5 \mu \mathrm{mol} / 1$, 最小值で $2.8 \mu \mathrm{mol} / 1$ を示す. 次いで $\mathrm{N}, \mathrm{VI}$ 海域が低く中央值で $5.3 \mu \mathrm{mol} / 1$, 最小值で $4.2 \mu \mathrm{mol} / 1$ 程度を示す。図-5（b）のCODは， IV 海域が最 も高く中央值で $2.3 \mu \mathrm{mol} / 1$ を示し, 次いで $\mathrm{V}$ 海域が高い. 図-5（c）のDINは，筑後川河口沖の I 海域が最も高い. 以上の水質環境特性から，2000年の夏季には，湾奥西 部の $\mathrm{V}, \mathrm{IV}, \mathrm{VI}$ 海域で低酸素化し, 貧酸素のレベルに低 下した時期があった．また，高い濃度のDINが筑後川か ら流入し, 湾奥北部沿岸の IV 海域は富栄養化が進行して いた.

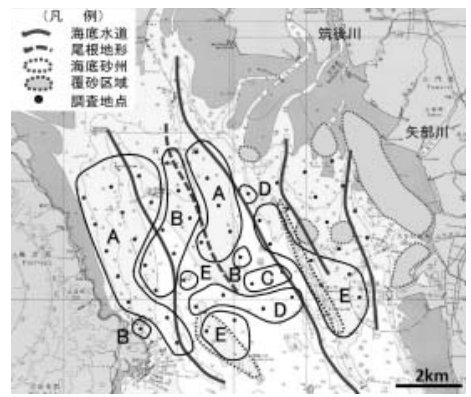

図-2 海域区分（底質デー夕，2000/9）
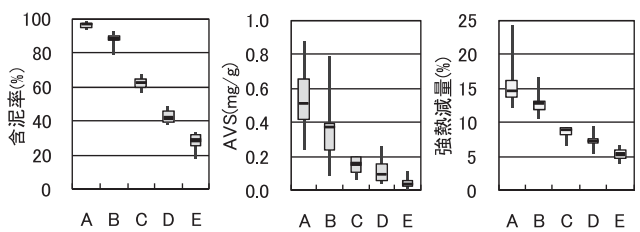

(a) 含泥率

(b) 強熱減量

(c) AVS

図-3 海域区分別の底質環境特性（2000/9）

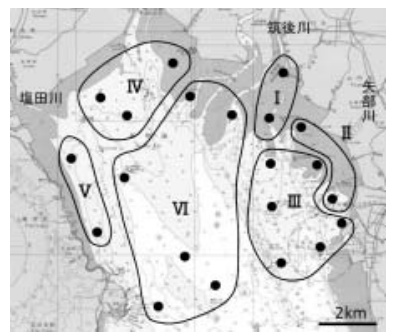

図-4 海域区分（底層水質デー夕，2000/7～9）

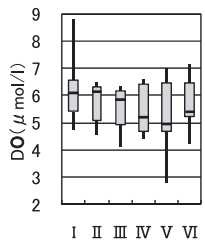

(a) DO

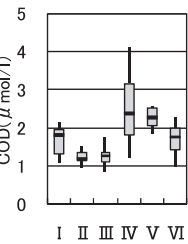

(b) COD

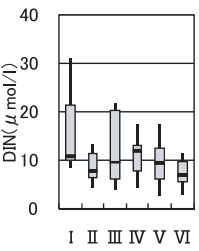

(c) DIN
図-5 海域区分別の水質環境特性（底層水質デー夕，2000/7～9）

\section{4. 底生生物の分布特性}

図-1に示した地点の軟体，環形，節足，棘皮動物の各 種数およびShannon-Wienerの多様度指数のそれぞれと底 質の含泥率，強熱減量，AVSにより，Ward法による凝 集型階層的クラスター分析を行い，図-6 (a) 〜 (e) に 示すような海域に分類した。また，海域区分別の含泥率， 強熱減量, AVS の頻度分布, 各種数と多様度指数の頻度 分布を図-7に示した。

底質デー夕・底生生物の種数, 多様度指数による海域 区分と底質デー夕単独の海域区分を比較すると，図-6 (a) ～(e) の海域区分は，図-6 左上の底質デー夕単独による 海域区分（図-2再掲）に極めて類似し，図-7 の含泥率， 強熱隇量，AVSの頻度分布は，図-3（a）〜（c）のそれ に極めて類似することから，底生生物の生息環境が，高 次分類群のレベルで底質の含泥率, 強熱減量, AVSであ らわされる底質環境特性に強く影響を受けていることが 伺える。

環境指標種について，二枚貝類種数に扔ける貧酸素耐 性種（シズクガイ，チヨノハナガイ，ヒメカノコアサリ） 


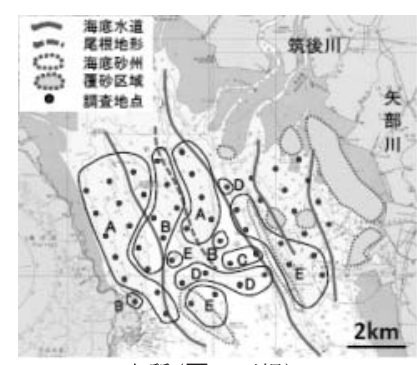

底質 (図-2再掲)

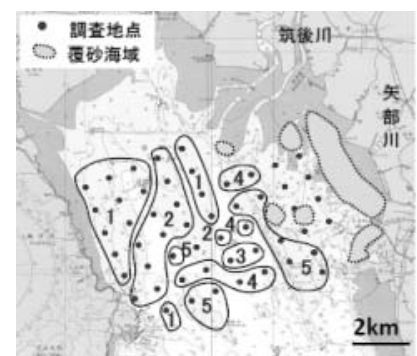

(c) 節足動物種数

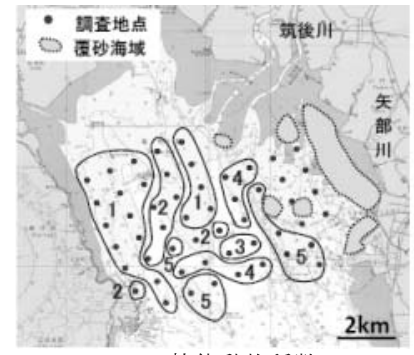

(a) 軟体動物種数

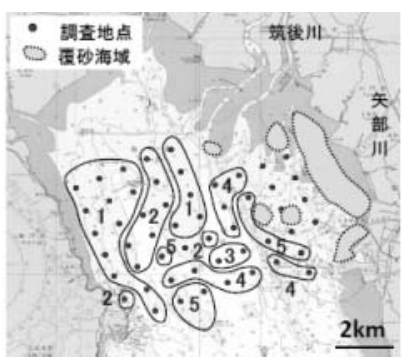

(d) 棘皮動物種数

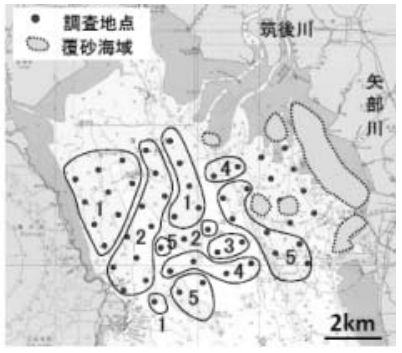

(b) 環形動物種数

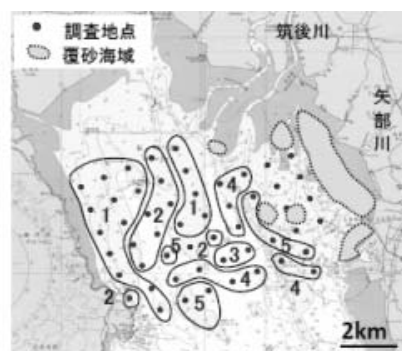

(e) 多様度指数

図-6 底質による海域区分および底質・高次分類群別種数，底質・多様度指数による海域区分（2000年9月）

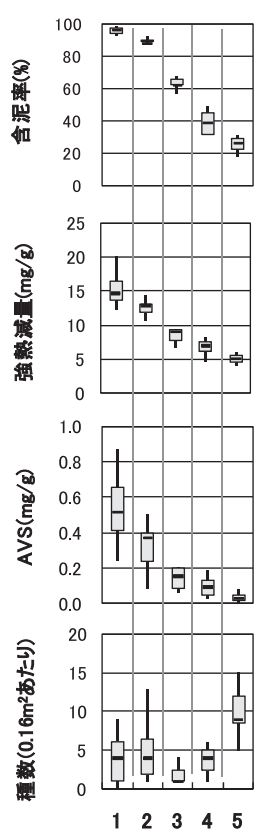

(a) 軟体動物種数

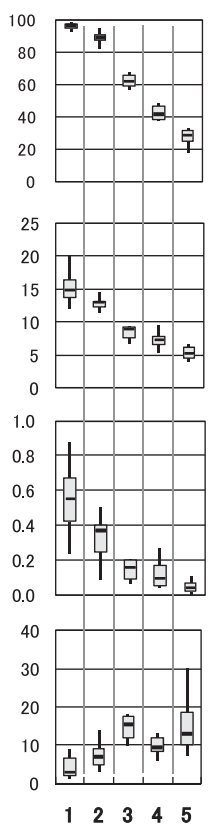

(b) 環形動物種数

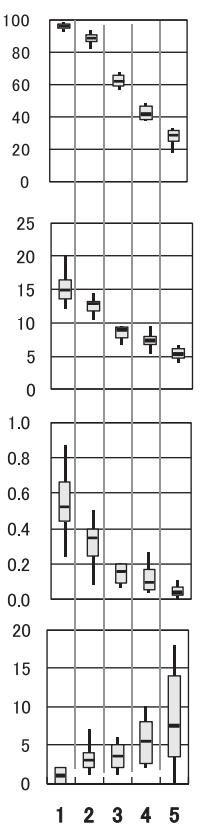

(c) 節足動物種数

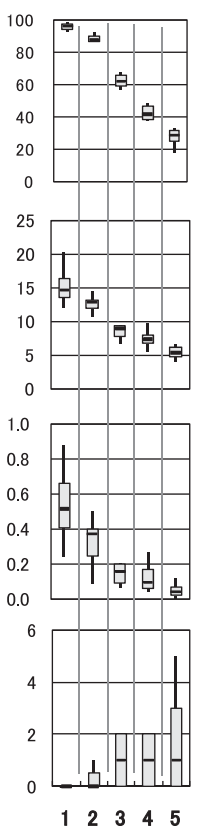

(d) 欶皮動物種数

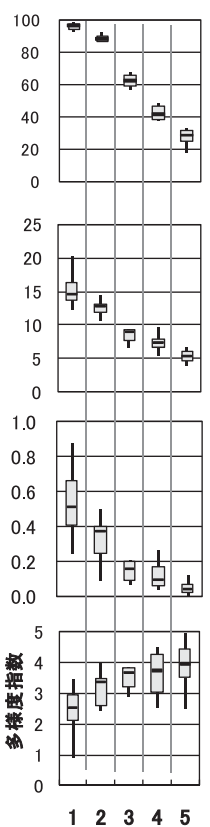

(e) 多様度指数

図-7＼cjkstart海域区分別の含泥率，強熱減量，AVS と高次分類群別種数，多様度指数（2000年9月）

の割合 $(\%)$ と底質の含泥率，AVS，強熱減量によりク ラスター分析を行った結果，図-8に示すような4つの海 域に分類された。海域区分のうち，a， d の海域区分で二 枚貝類種数における貧酸素耐性種の割合が中央值で $30 \%$ 以上になる。

貧酸素耐性種と底質環境特性との関連についてみると, 図-9（a）～（d）から，二枚貝類種数における貧酸素耐性
種の割合と含泥率，強熱減量，AVSの間には，明瞭な相 関はみられない。一方, 貧酸素耐性種と水質環境特性と の関連についてみると, 図-8から, この割合が中央值で $30 \%$ 以上海域は，底層水質による海域区分のIII, V, VI 海域内に分布する。これらの海域は, 底生生物調査が行 われた 2000 年の夏季に低酸素化〜貧酸素化していること から, 低酸素化〜貧酸素化した底層の水質環境が貧酸素 


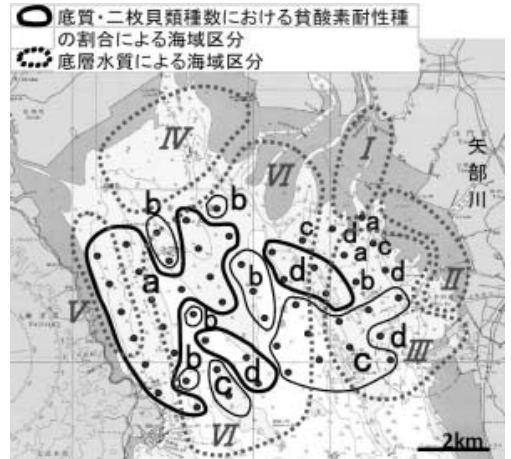

図-8 二枚貝類種数における貧酸素海域区分 (2000年9月)

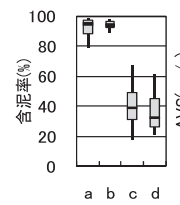

(a) 含泥率

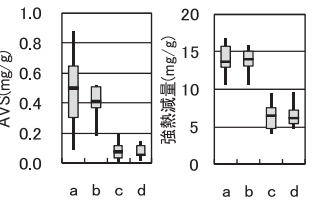

(b) 強熱減量 (c) AVS

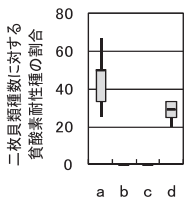

(d) 貧酸素而性種 の割合
図-9 海域区分別の底質環境特性および貧酸素耐性種の分布特性 (2000年9月)

耐性二枚貝類の分布に影響を及ぼしていることが伺える.

\section{5. 浮泥の堆積特性}

図-10に示す地点で，2008年 8 月〜 11月に浮泥分布調 查が行われた（九州農政局，2008）。浮泥の明確な定義 はないが，通常，有機物を多く含み，保水能力が非常に 高く，比重が小さく，海底に沈降するが圧密しがたい状 態のものをいう（日比野ら，2006）。本調查では，潜水 士によりアクリルパイプ（長さ $60 \mathrm{~cm}$, 内径 $100 \mathrm{~mm}$ ）を 底泥に挿入し，立てたままの状態で回収後 2 時間以上静 置し，懸濁物が沈降した状態で，最も表層部分にある極 めて粒度が細かく流動性が高い層の厚さを浮泥厚として 測定している。図-11に，2008年8月1日の浮泥厚の分布 を示した。有明海湾奥部の海底地形の特徵は, 筑後川, 六角川, 塩田川等の流入河川に連続する海底水道と, こ れに並列する尾根の高まりや野崎ノ州, 蜂ノ州等の海底 砂州が北北西〜南南東に数列分布する. 浮泥と海底地形 との関連についてみると, 図-11から, 浮泥は海底水道 の西側斜面，海底砂州の東側斜面で厚くなる傾向がみら れる。また，浮泥の堆積と流れとの関連についてみると， 有明海の湾奥部では, 図-12に示すように，反時計回り に卓越する恒流が，海底水道や海底砂州等の海底起伏の 影響を受けながら湾奥から湾口に向かって流下する．浮 泥は，このような流れの影響を受けて，流れの外側にあ たる海底水道の西側斜面，海底砂州の東側斜面に堆積す る状況が考えられる。

\section{6. まとめ}

本研究では, 底質, 水質, 底生生物, 海底地形, 潮流 等の既往デー夕と浮泥分布の現地調查結果から，有明海 湾奥部の底質の堆積環境特性と底生生物の分布特性を調 ベた。

\section{（1）底質環境特性}

表-1から，クラスター分析で $\mathrm{A}$ 海域に分類された塩田 川沖海底水道と住之江川沖海底水道の両西側斜面一带で 最も悪化し，次いで，クラスター分析で $\mathrm{B}$ 海域に分類さ れた塩田川沖海底水道の東側斜面から谷底一帯にかけて

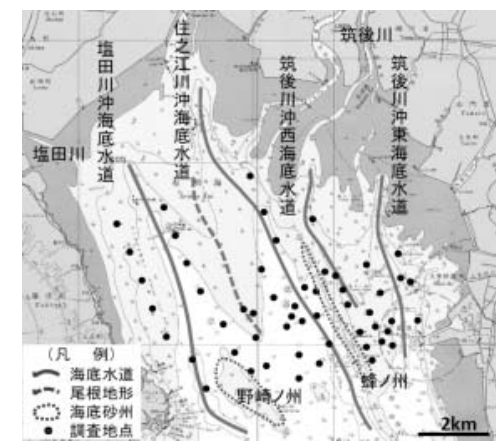

図-10 浮泥分布調查地点（2000年8月～11月）

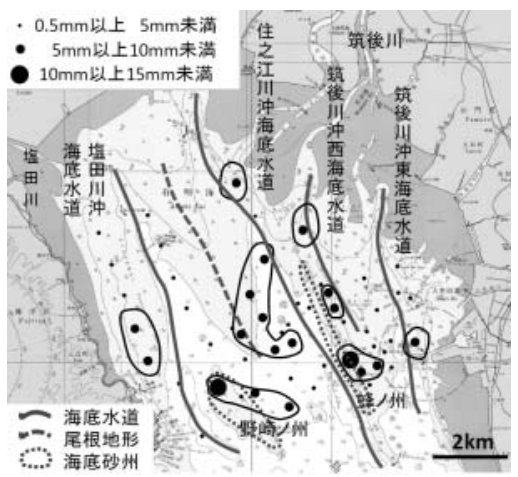

図-11 浮泥層厚の分布（2008年 8 月 1 日大潮満潮時前後）

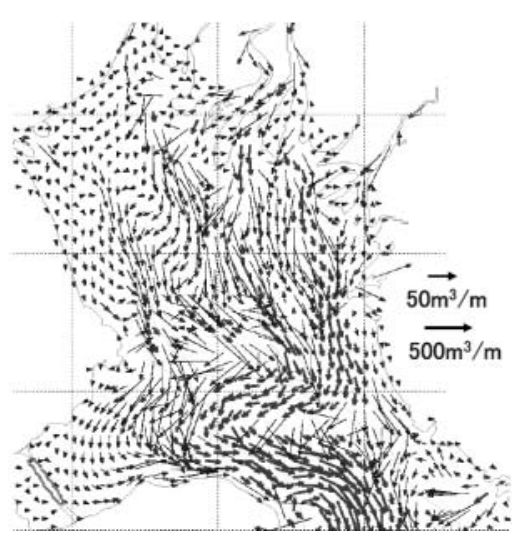

図-12 有明海湾奥部の恒流（滝川ら，2002） 
悪化が進んでいる。 また，クラスター分析でE海域に分 類された野崎ノ州や蜂ノ州等の砂州とその周辺では, 強 熱減量とAVSの值からみるかぎり, 底質の悪化は進んで いない.

\section{（2）底生生物の分布特性}

前述のように, クラスター分析による底質単独の海域 区分と底質 - 底生生物種数の海域区分は極めて類似して いるので, 底生生物種数を底質単独のクラスター分析に よる海域区分にあてはめ, 表-2に示した。表-1および表2 から, 底質環境の泥化, 富栄養化, 貧酸素化の悪化の 程度に対応して高次分類群別の出現種数が変動すること が明らかになった。底質環境の悪化がみられるB海域で, 軟体動物の種数が増加しているのは, シズクガイ, チョ ノハナガイ, ヒメカノコアサリの小型短命の貧酸素耐性 種を含む二枚貝類種数の変動が影響している。また， C 海域で環形動物の種数が増加しているのは, Sigambra tentaculata, Mediomastus sp., ウミイサゴムシ等の富栄養 化指標種を含むゴカイ類の種数の変動が影響している. 水質環境特性との関連では, 底生生物調査が行われた夏 季に, 二枚貝類種数における貧酸素耐性種の割合が増加 する海域が, 底層水質のDOが低下する海域内に分布す ることから, 底層の水質環境が貧酸素耐性二枚貝類の生 息に影響を及ぼしていることが伺える。

\section{（3）浮泥の堆積特性}

浮泥は, 住之江川沖海底水道や筑後川沖西海底水道の 西側斜面, 蜂ノ州や野崎ノ州の海底砂州の東側斜面等に 堆積する傾向がみられた，有明海の湾奥部では, 反時計 回りに卓越する恒流が, 海底水道や海底砂州等の海底起 伏の影響を受けながら湾奥から湾口に向かって流下す る. 浮泥は，このような流れの影響を受けて，流れの外 側にあたる海底水道の西側斜面, 海底砂州の東側斜面に

表-1 海域区分別の底質環境特性（25\%值～75\%值）

\begin{tabular}{c|c|c|c}
\hline 海域 & 含泥率 $(\%)$ & 強熱減量 $(\mathrm{mg} / \mathrm{g})$ & $\mathrm{AVS}(\mathrm{mg} / \mathrm{g})$ \\
\hline $\mathrm{A}$ & $95 \sim 97$ & $14 \sim 16$ & $0.4 \sim 0.66$ \\
\hline $\mathrm{B}$ & $87 \sim 90$ & $12 \sim 13$ & $0.24 \sim 0.4$ \\
\hline $\mathrm{C}$ & $59 \sim 66$ & $8 \sim 9$ & $0.1 \sim 0.2$ \\
\hline $\mathrm{D}$ & $39 \sim 47$ & $7 \sim 8$ & $0.06 \sim 0.17$ \\
\hline $\mathrm{E}$ & $25 \sim 32$ & $5 \sim 6$ & $0.03 \sim 0.07$ \\
\hline
\end{tabular}

表-2 底生生物の $0.16 \mathrm{~m}^{2}$ あたりの種数（25\%值〜 $75 \%$ 值）

\begin{tabular}{c|c|c|c|c|c}
\hline 海域 & $\begin{array}{c}\text { 全底生 } \\
\text { 生物 }\end{array}$ & $\begin{array}{c}\text { 軟体 } \\
\text { 動物 }\end{array}$ & $\begin{array}{c}\text { 環形 } \\
\text { 動物 }\end{array}$ & $\begin{array}{c}\text { 節足 } \\
\text { 動物 }\end{array}$ & $\begin{array}{c}\text { 嗏皮 } \\
\text { 動物 }\end{array}$ \\
\hline $\mathrm{A}$ & $4 \sim 6$ & $1 \sim 6$ & $2 \sim 7$ & $0 \sim 1$ & 0 \\
\hline $\mathrm{B}$ & $11 \sim 15$ & $2 \sim 7$ & $5 \sim 9$ & $2 \sim 4$ & $0 \sim 1$ \\
\hline $\mathrm{C}$ & $18 \sim 28$ & $1 \sim 3$ & $12 \sim 18$ & $2 \sim 5$ & $0 \sim 2$ \\
\hline $\mathrm{D}$ & $15 \sim 26$ & $3 \sim 5$ & $9 \sim 12$ & $3 \sim 8$ & $0 \sim 2$ \\
\hline $\mathrm{E}$ & $40 \sim 49$ & $9 \sim 12$ & $10 \sim 19$ & $4 \sim 14$ & $1 \sim 3$ \\
\hline
\end{tabular}

堆積する状況が考えられる。 今後, 湾奥部における底層 流の状況を把握し, 浮泥の運搬・堆積と底層流の関係を より定量的に明らかにする必要がある。なお, 有明海の 湾奥部では, 筑後川等からの矁濁物質が有機物質等を吸 着して浮泥が形成されるとともに, 底泥や底層付近での 植物プランクトン等の分解や腐敗に由来する浮泥の形成 も考えられるので, 今後, 浮泥の起源について明らかに する必要がある。

\section{参 考 文 献}

安藤晴夫 ・ 川井利夫（2007）：東京都内湾における底生生物 生息状況の解析結果について, 東京都環境科学研究所年 報, pp.78-84.

大隈 斉・江口泰蔵・川原逸郎・伊藤史郎（2001）：有明海 湾奥部の底質およびマクロベントス，佐賀県有明水産振 興センター研究報告, 第20巻, pp.55-62.

九州農政局（2008）：平成20年度有明海底質環境調查報告書. 古賀秀昭（1991）: 有明海北西海域の底質及び底生生物, 佐 賀県有明水産振興センター研究報告, 第 13 巻, pp.57-80.

佐賀県有明水産振興センター（2000）：マクロベントス調査 結果.

園田吉弘・滝川 清・齋藤 孝（2008a）：有明海における赤 潮発生と海域環境の変動特性, 第 33 回海洋開発論文集, pp.615-620.

園田吉弘 · 滝川 清 - 床次武富 - 早田 功 - 齋藤 孝 （2008b）：有明海における水質・底質の実測デー夕に基 づく海域環境の変動特性, 第 55 回海岸工学論文集, pp.1021-1025.

園田吉弘 - 滝川 清 - 床次武富 - 今村義郎 - 田㴊幹修 - 齋藤 孝（2009）：有明海における底質環境特性と底生生物の 分布特性, 第 34 回海洋開発論文集.

滝川 清 - 田㴊幹修 (2002) : 有明海の潮汐変動特性と沿岸 構造物の影響, 第49回海岸工学論文集, pp.1061-1065.

日比野忠史・松本英雄（2006）：広島湾に分布する浮泥の特 性と季節的な性状変化, 土木学会論文集 B, Vol.62, No.4, pp.348-359.

棟近雅彦・野澤昌弘（2007）：JUSE-Statworksによる多変量解 析入門, 日科技連, pp.207. 